\title{
Bronchial Mucosa-Associated Lymphoid Tissue Lymphoma
}

National Cancer Institute

\section{Source}

National Cancer Institute. Bronchial Mucosa-Associated Lymphoid Tissue Lymphoma.

NCl Thesaurus. Code C5264.

An extranodal marginal zone lymphoma that arises from the lung. It is characterized by the neoplastic proliferation of small B-lymphocytes, monocytoid cells and cells with plasma cell differentiation in the marginal zones of reactive lymphoid follicles. The neoplastic cells infiltrate the interfollicular areas and the bronchial epithelium forming lymphoepithelial lesions. The neoplasm is usually discovered as a mass in a chest $\mathrm{x}$-ray in asymptomatic patients. When symptoms occur, they include cough, dyspnea, hemoptysis, and chest pain. If the lung lesions are resectable, surgery can result in prolonged remission. 